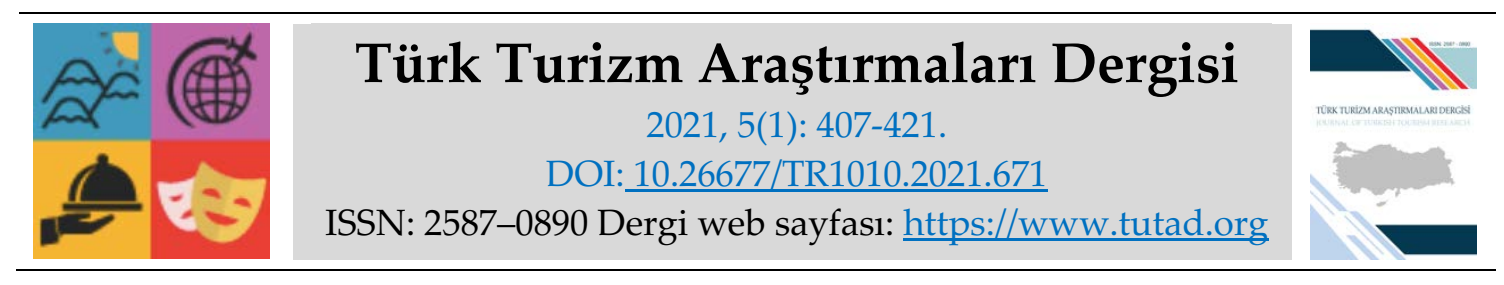

ARASTTIRMA MAKALESI

\title{
Dijital Seyahat Aracılarında E-Müşteri Tatmini ve E-Şikayetlere Yönelik Bir İçerik Analizi
}

Anıl KÜTÜK, Doktora Öğrencisi, Dokuz Eylül Üniversitesi, Sosyal Bilimler Enstitüsü, İzmir, eposta: anilkutuk89@gmail.com

ORCID: https://orcid.org/0000-0002-1563-874X

Öz

İnternetin hayatın her alanına yayılması ile birlikte seyahat aracıları da faaliyetlerini internete taşıyarak dijital seyahat aracılarına dönüşmüştür. Dijital seyahat aracıları, fiziksel olarak bir ofisleri olmasa da ekonomik faaliyetlerini sürdürüp turizm sektörünün çarklarının dönmesine katkı sağlamaktadır. Ancak dijital seyahat aracıları da özünde bir ticari işletme olduğundan, kâr amacı gütmek, müşteri devamlılığı sağlamak ve bunu da müşteri tatmini ile gerçekleştirmek durumundadır. Bu çalışmada müşteri tatmininin sağlanmasında kilit rolü bulunan ve önemli bir bilgi kaynağı olan müşteri e-şikayetlerinin dijital seyahat aracıları tarafından nasıl değerlendirildiğinin incelenmesi amaçlanmıştır. Bu amaca dönük olarak da sikayetvar.com isimli internet sitesi üzerinde sundukları hizmetlere ilişkin şikâyet belirtilen 20 dijital seyahat aracısına yönelik sikayetvar.com'a iletilen şikayetler incelenmiştir. Sonuç olarak, dijital seyahat aracıları hakkındaki en çok şikâyet edilen konuların rezervasyon iptali ve iptal edilen rezervasyonun ücretinin iadesi üzerinde yoğunlaştığı görülmüştür. Şikayetlerin yalnızca \%18,44'ü ilk bir hafta içerisinde çözülürken, 15 gün içerisinde çözülen şikayetlerin oranı \%24, 15 gün ila 1 ay içerisinde çözülen şikayetlerin oranı ise $\% 21,78$ 'dir. Tüm şikayetlerin ise yalnızca $\% 15,31$ 'i çözüme kavuşturulmuştur.

Anahtar Kelimeler: Dijital Seyahat Aracıları, Müşteri Tatmini, E-Tatmin, E-Şikâyet.

Makale Gönderme Tarihi: 09.12.2020

Makale Kabul Tarihi: 11.03.2021

\section{Önerilen Atıf:}

Kütük, A. (2021). Dijital Seyahat Aracılarında E-Müşteri Tatmini ve E-Şikayetlere Yönelik Bir İçerik Analizi, Türk Turizm Araştırmaları Dergisi, 5(1): 407-421.

(C) 2021 Türk Turizm Araştırmaları Dergisi. 


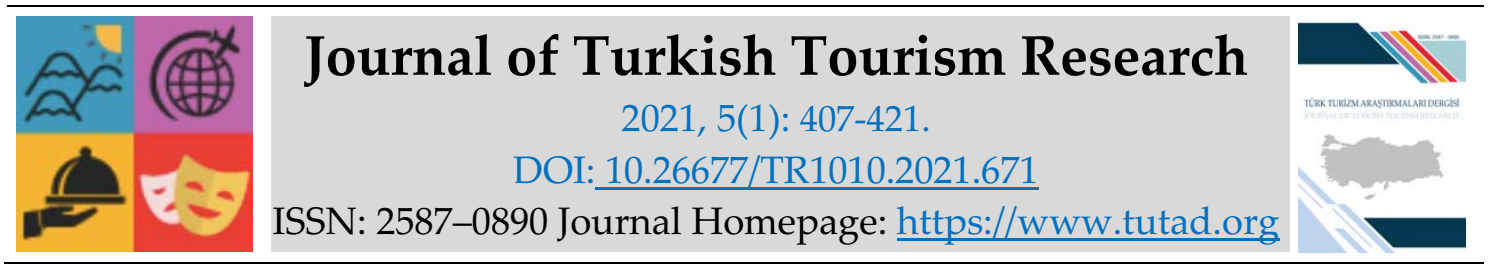

\title{
$\underline{\text { RESEARCH PAPER }}$
}

\section{E-Customer Satisfaction in Digital Travel Intermediaries and a Content Analysis Intended for E-Complaints}

Anıl KÜTÜK, PhD. Student, Dokuz Eylül University, Social Sciences Institute, İzmir, e-mail: anilkutuk89@gmail.com

ORCID: https://orcid.org/0000-0002-1563-874X

\begin{abstract}
With the spread of the internet in all areas of our lives, travel agents have turned their activities into digital travel agents by moving their activities to the internet. Even though digital travel agents do not have a physical office, they continue their economic activities and contribute to the turning of the wheels of the tourism industry. However, since digital travel agents are in essence a commercial enterprise, they must pursue profit, ensure customer retention and achieve this with customer satisfaction. In this study, it was aimed to examine how customer e-complaints, which play a key role in ensuring customer satisfaction and are an important source of information, are evaluated by digital travel agents. For this purpose, complaints submitted to sikayetvar.com for services offered regarding 20 digital travel agents on the website sikayetvar.com were examined. As a result, it has been observed that the most complained issues about digital travel agents are the cancellation of the reservation and the refund of the canceled reservation. While only $18.44 \%$ of complaints are resolved within the first week, the rate of complaints resolved within 15 days is $24 \%$, and the rate of complaints resolved within 15 days to 1 month is $21.78 \%$. Only $15.31 \%$ of all complaints were resolved.
\end{abstract}

Keywords: Digital Travel Intermediaries, Customer Satisfaction, E-Satisfaction, E-Complaint. Received: 09.12.2020

Accepted: 11.03 .2021

\section{Suggested Citation:}

Kütük, A. (2021). E-Customer Satisfaction in Digital Travel Intermediaries and a Content Analysis Intended for E-Complaints, Journal of Turkish Tourism Research, 5(1): 407-421.

(C) 2021 Türk Turizm Araştırmaları Dergisi. 


\section{Gíriş}

Turizm alanında artan teknolojik gelişmeler, sektörel anlamda müşterilerin de üretime katılımını sağlamaktadır. Bu, özellikle müşterilerin tatil planları araştırması, online rezervasyon, satın alma ve check-in işlemleri yoluyla sağlanmaktadır. Dolayısıyla bu durum işletmelerin müşteri odaklı stratejiler geliştirmeleri gereksinimini ortaya çıkarmaktadır (Arıca ve Kozak, 2018: 685). Dünyamızda giderek artan teknoloji odaklı tüketici karar verme süreçleri de artık dijital(çevrimiçi) ortama göre şekillenmeye başladığından, dijital ortamlarda satın alma davranışı özellikle bilgi arama kısmında tüketicilere çok önemli olanaklar sunmaktadır. Web taraması ve buralardaki tüketici şikayet ve yorumları, tüketici davranışı üzerinde satın alım sürecinde büyük etkiye sahip olmaktadır.

Günümüzde hemen her konaklama işletmesinin bir web sitesi olsa da rezervasyon ve satışa yönelik fonksiyonlarının iyi çalışmaması nedeniyle dijital platformlar rezervasyon ve satış konusunda öne çıkmaktadır (Kozak ve Cingi, 2019: 177). İnternetin yaşamın her alanında yer bulmaya başlamasıyla, seyahat planlarının ve rezervasyonların çoğunluğu da bu kanallar üzerinden yürütülmektedir. Özellikle online seyahat acenteliği ile bu platformlarda yer alan işletmeler online hizmet vermeye başlamıştır. İnternet ortamında müşterilere günün her saatinde rezervasyon ve tercih edilen destinasyona ilişkin bilgiler sunan bu işletmeler, farklı alternatifleri bir arada görmeyi de sağlamaktadır (Buluk ve Boz, 2016: 505).

Öte yandan müşteriler, internetin sağladığı imkanlar doğrultusunda çok fazla seçenek olması nedeniyle her zamankinden daha fazla güce sahiptir. Bu nedenle, yoğun rekabet ortaminda hayatta kalmak ve rekabet avantajı kazanmak isteyen bir dijital seyahat aracısının müşteri odaklı olması giderek önem kazanmaktadır. İnternet bağlamında müşteri tatmini araştırmaları, memnuniyetin sadece kritik bir performans sonucu değil, ayn zamanda internet perakendecisinin başarısının temel belirleyicisi olduğuna vurgu yapmaktadır (Christodoulides ve Michaelidou, 2011).

Dijital seyahat aracıları özelinde müşteri tatminine yönelik çalışmalar, genel olarak aracı işletmelerin turizm pazarında büyük bir değişim yarattığını göstermektedir. Birçok araştırma çevrimiçi turizm pazarının büyümesini ve çevrimiçi hizmetlerin kullanımıyla müşteri memnuniyetinin arttı̆̆ını ortaya koymuştur (Anderson ve Srinivasan, 2003: 124). Bu çalışmalar, başarılı bir çevrimiçi deneyimin ve sağlanan e-müşteri tatmininin kullanıcıların gelecekteki çevrimiçi satın alma niyetlerini etkilediğini göstermiştir (Tang ve Jang, 2008).

Müşteri ile bire bir iletişim kuran turizm sektörünün en büyük oyuncularından olmasına rağmen dijital seyahat aracılarının fiziksel olarak müşterileri ile bir araya gelecek bir ofisinin olmaması nedeniyle şikayetlerin çözümü konusu kendileri için hayati önem taşımaktadır. Müşteri şikayetlerinin çözümü, müşteri memnuniyeti yaratıp müşteri sadakati oluştururken, aynı zamanda ekonomik kayıpların da önüne geçmektedir (Unur vd., 2010). Bu bağlamda dijital seyahat aracılarının şikayetlerini ne şekilde işlediğinin incelenmesi, dijital seyahat aracıları müşterilerinin e-tatmin düzeyini belirleyip hangi konularda iyileştirme yapmaları gerektiğini belirlemesi bakımından önem taşımaktadır.

\section{KAVRAMSAL ÇERÇEVE}

\section{Dijital Seyahat Aracıları}

Bugün dünya çapında hükümetler arası en büyük turizm kurumu olan Birleşmiş Milletler Dünya Turizm Örgütü (UNWTO)'ne göre seyahat acentesi, koordinasyonu yoğun, merkezinde iletişim ve bilgi işleme olan bir endüstridir. Dünya Turizm Örgütü'nün (UNWTO, 2002) tanımına göre: 
"seyahat acenteleri, insanlara seyahatler, konaklama ve ulaştırma, konularında bilgi veren ve belli bir komisyon alarak, tur operatörlerinin ürünlerini belirlenen fiyatlarla müşteriye satışına aracılık eden kuruluşlardır" (Kozak, 2004: 31). Bunun yanında seyahat acentesini "turizm endüstrisi içinde turistik talep ile arzın karşılıklı etkileşimini sağlayan bir fonksiyonu gerçekleştiren ve bütünüyle hizmet üreten işletmeler" olarak da tanımlamak mümkündür (İçöz, 2003: 72).

Dijital seyahat aracıları ise, internet üzerinden satış yaparak, tek bir merkezden dünyanın her yerindeki turizm işletmelerinin hizmetlerinin satışına aracılık eden işletmelerdir. Dijital seyahat aracıları, turistlere bilgi sunmalarının yanında konaklama işletmelerinin pazarlama ve tanıtım maliyetlerinin düşmesini de sağlamaktadır. Kısacası dijital seyahat aracıları, internet üzerinden seyahat ürününün pazarlanmasını ve bağlantılı hizmetlerin sağlanmasını çevrimiçi (dijital) ortamlar üzerinden yürüten ticari işletmelerdir (Ay, 2009: 128).

Dijital seyahat aracıları, geleneksel seyahat acentelerinden farklı olarak tüm faaliyetlerini çevrimiçi kanallar üzerinden, web siteleri ya da mobil uygulamalar aracılığıyla gerçekleştirmektedir. Bu doğrultuda dijital seyahat aracıları, müşterilerine günün her saatinde, her yerde en hızlı şekilde konaklama ve ulaşım bileti (uçak, otobüs, gemi, tren vb.) gibi hizmetlere ilişkin rezervasyon yapabilme, tercih edilen seyahat destinasyonlarına ilişkin bilgilendirme ve bu destinasyonlardaki konaklama alternatiflerini karşılaştırabilme hizmetlerini sunmaktadır (Long ve Shi, 2017: 304). İnternet üzerinden zamandan ve mekândan bağımsız olarak hizmet sunabilme ayrıcalığı, dijital seyahat aracılarının her geçen gün daha da popüler olmasını sağlamaktadır. Bu doğrultuda bilgi iletişim teknolojileri ve internetin gelişimiyle beraber tüketici talep ve beklentileri de değişime uğramıştır. Geçmişe kıyasla, yoğun şekilde interneti kullanabilen seyahat endüstrinin müşterileri de günümüzde bilinçli ve farkındalı̆̆ yüksek müşteriler halini almıştır (Kutlu vd., 2019: 43).

\section{Elektronik Müsşteri Tatmini}

Günümüzde hemen her sektörde kaliteli hizmet sunmak ve müşteri memnuniyeti sağlamak, başarıya giden yolda önemli faktörler olarak kabul edilmektedir. Rekabetin yoğunlaşması ve bilgi teknolojilerinin gündelik hayata daha çok girmeye başlaması ile müşterileri beklentileri doğal olarak artmaktadır. Dolayısıyla bu durum işletmelerin müşteri odaklı stratejiler geliştirmeleri gereksinimini ortaya çıkarmaktadır (Arıca ve Kozak, 2018: 685). Bilgili ve bilinçli müşteriler, tam olarak ne istediklerini bilerek seçim yapmaktadır. Turizm ve seyahat endüstrisinde de çevrimiçi ortamda ürün ya da hizmet satın alımlarının yaygınlaşmasının bir sonucu olarak e-müşteri tatmini kavramı günden güne daha fazla ele alınmaktadır. Bu doğrultuda e-müşteri tatmini, müşterilerin internet aracılığ 1 ile çevrimiçi işletmelerden gerçekleştirmiş oldukları satın alımlar sonucunda, tüm beklentilerini karşılayıp, pozitif deneyim elde ederek ayrılmaları şeklinde tanımlanmaktadır (Anderson ve Srinavasan, 2003: 125). Yapraklı ve Yllmaz'a (2008: 141) göre ise e-müşteri tatmini "elektronik ortamda hizmet veren bir firmaya yönelik geçmiş dönemdeki satın alımlarla ilgili memnuniyet duyma veya hoşnut olma durumu" şeklinde açıklanmaktadır.

Teknolojik gelişmelerle birlikte, çevrimiçi ortamda e-tatmin olarak görülen müşteri tatminini incelemek için önemli sayıda araştırma yapılmaya başlanmıştır. Tatmin kavramına benzeyen etatmin, müşterilerinin çevrimiçi (ya da elektronik) bir işletmeden gerçekleştirilen daha önceki satın alımların bir sonucu olarak değerlendirilmektedir ve kavram aynı zamanda önceki satın alım sürecinde müşterilerin ürün kullanım deneyimine odaklanmaktadır (Luo ve Lee, 2011: 827). 
Çetinsöz (2016) araştırmasında çevrimiçi ortamlarda gerçekleşen seyahat alışverişlerinde etatminin temel belirleyicileri olarak 6 boyutu öne çkmaktadır. Bunlar; müşteriye sunulan hizmetin kalitesi, erişimde kolaylık, web sitelerinin tasarımı, ürün seçimi, bilgilendirme (müşteri ile ilgilenme), ve güvenlik olarak belirlenmiştir. Literatürde yer alan birçok çalışma tarafından da belirlenen bu boyutlar, e-tatminin önemli unsurları olarak kabul edilmektedir.

Genel olarak sadece dijital seyahat aracıları özelinde müşteri tatminine yönelik araştırmaların çok sınırlı sayıda olduğu, buna karşılık turizm alanında e-tatmin, e-ağızdan ağıza pazarlama (e-wom) ve e-şikayetlere yönelik araştırmaların ise son yıllarda çok daha fazla gerçekleştirildiği literatürde göze çarpmaktadır. Örneğin; Mohammed vd., (2016), 170 çevrimiçi turizm müşterisi ile Mısır'da gerçekleştirdikleri çalışmalarında web sitesinin interaktifliği ve güvenilirliğinin e-müşteri tatminini en fazla etkileyen konular olduğu, buna karşllık gizliliğin ise müşterilerin e-tatmini için fazla etkili olmadığını belirlemiştir.

Bir başka araştırmada Pereira vd. (2017), e-müşteri memnuniyetinin çevrimiçi belirleyicilerini Portekiz'in lider turizm seyahat aracısının 3188 müşterisi ile incelemiştir. Araştırmadan elde edilen bulgular, web sitesinin görünümü, kullanım kolaylığı ve sitede yer alan bilgilerin kalitesinin e-müşteri memnuniyetini etkilediğini göstermiştir.

Mahadin vd. (2020), Ürdün'ü ziyaret eden 258 ABD'li turist ile web sitelerinin özelliklerinin (kullanıcı dostu olma, bilgi kalitesi, eğlence, güvenlik ve mahremiyet) turistlerin e-memnuniyeti üzerindeki etkilerini ve turistlerin e-memnuniyetlerinin tutumsal e-sadakat üzerindeki etkilerini incelemiştir. Araştırmadan elde edilen bulgular, kullanım kolaylığı, bilgi kalitesi, güvenlik ve mahremiyetin turistlerin e-memnuniyetleri üzerinde olumlu etki yarattığını ortaya koymuştur.

İran'da gerçekleştirilen bir araştırmada ise turistlerin İranlı turizm web sitesine yönelik esadakatlerini, 384 İranlı e-turizm müşterisi özelinde incelenmiştir. Araştırmadan elde edilen bulgular, müşterilerin e-tatminlerinin ve e-güvenlerinin e-sadakatleri üzerinde pozitif etkisi olduğunu ortaya koymuştur (Gharibi, Rudsari ve Nasouti, 2020).

Ronsana vd., (2018) ise e-turizm pazarında (dijital aracılarda) müşterilerin e-sadakatlerini etkileyen faktörleri incelemiştir. Araştırmadan elde edilen bulgular, müşterilerin e-sadakatinin, e-algılanan değer ve e-güven aracılığıyla e-hizmet kalitesi tarafından önceden belirlendiğini göstermektedir.

Husain vd., (2019) ise, e-turizmde kredi kartı ile gerçekleştirilen alışverişlerde e-tatmini, 842 eturizm müşterisi özelinde incelemiştir. Buna göre; web sitesinin erişim kolaylığı, satış alt yapısı, web site tasarımı ve finansal güvenliğinin, e-turizmde gerçekleştirilen kredi kartıyla yapılan işlemlere yönelik e- müşteri tatmininde önemli bir rol oynayan önemli faktörler olduğunu ortaya koymuştur.

Özetle konuya ilişkin literatürde bugüne dek gerçekleşen çalışmalardan da görüldüğü üzere, müşterilerin e-tatminleri, sonuç olarak e- güven ve e-sadakati artırmaktadır. Bu durum ise satışları artırarak işletmeler açısından karlılı̆̆ın artımını sağlamaktadır. Bu bağlamda, e-tatmini sağlamak adına müşterilerin hizmet satın alım sürecinde hangi konulara ilişkin şikayet ilettiğini belirlemek, işletmeler adına e-tatmini sağlayabilmenin bir başlangıç noktasıdır.

\section{E-Şikâyet}

Kelime olarak Arapçadan dilimize geçen şikayet kavramı, hoşnutsuzluk ve yakınma anlamlarına gelmektedir. Turizm endüstrisinde ise şikayet kavramı, turizm işletmelerinden hizmet satın alan müşterilerin hoşnutsuzluklarını geri bildiri aracılığıyla ifade ederek, üretim, satış, pazarlama ve dağıtım süreçlerine müdahil olmaları durumudur (Ayyıldız ve Baykal, 2020: 2662). 
Teknolojinin gelişimi ile birlikte hayatımıza giren e-şikâyet veya çevrim içi şikâyet kavramı ise; duygu ve bilgi paylaşımı adına, diğer müşterilerin de göreceği şekilde internet aracılığı ile müşterilerin satın alınan ürün ve hizmete ilişkin dönütleri olarak tanımlanmaktadır (Dinçer ve Alrawadieh, 2017: 4). Bir başka tanıma göre ise e-şikâyet; "bir ürün veya hizmet satın alan müşterinin, bu deneyimde yaşadığı olumsuzlukları internet aracılığıyla elektronik ortamlarda dile getirmesidir (Şahin, Girgin ve Kazaoğlu, 2018: 71). İlk bakışta, e-şikayetler çevrimiçi ortamlarda yer alan turizm işletmeleri açısından bir kaygı unsuru olarak görünseler de ürün ve hizmetlerin iyileştirilmesi ve müşteri taleplerine hitap eden stratejilerin geliştirilmesi adına işletme kalitesinin artırımına yönelik bir fırsat olarak da görülebilir (Şahin, 2018: 54). Müşteriler bu çevrimiçi ortamlarda işletme ile ilgili deneyimlerine bağlı olarak memnun kalma düzeylerini belirtebilmekte, işletmeden beklentilerini bildirmekte, puanlama yaparak yıldız verebilmekte ve yorum yapabilmektedirler. Diğer kişiler ise yapılan bu yorumları okuyarak yorumlara katılma derecelerini belirtebilmektedir. Çevrimiçi ortamda yapılan bu müşteri yorumları, seyahat işletmelerinin sunmuş olduğu hizmete ilişkin performanslarını müşterinin bakış açısıyla değerlendirmesine olanak tanımaktadır ve memnun kalmama unsurlarının belirlenmesi ve beklentilerin anlaşılması noktasında büyük önem taşımaktadır.

E-şikayete ilişkin literatür incelendiğinde, yine sikayetvar.com internet sitesinde yer alan müşteri şikayetleri ile ilişkili gerçekleşen bazı akademik çalışmalar göze çarpmaktadır. Örneğin; Çulha vd. (2009), otel işletmelerine yönelik müşteri şikâyetlerinin hangi temalar (kategoriler) da toplandığının belirlendiğini ölçen çalışmalarında sikayetvar.com un da aralarında bulunduğu 3 sanal şikâyet sitesini içerik çözümlemesi yöntemi ile incelemiştir. Çalışma sonucunda, 8 temel ve 42 alt tema (kategori) tanımlanmıştır. Sunulan yiyecek-içecek hizmetlerine yöneltilen şikâyetlerin en fazla yöneltilen şikâyet teması olduğu görülmüştür. En fazla karşılaşılan alt temayı ise iş gören tutum ve davranışlarının oluşturduğu belirlenmiştir.

Cevher (2016) ise, yükseköğretim alanında faaliyet gösteren kamu ve vakıf üniversitelerine ilişkin iletilen şikayetleri incelemiştir. Çalışmada, üniversitelere yönelik şikayetlerin içeriğini tespit etmek amaciyla "sikayetvar.com" sitesinde yer alan şikayetler, içerik çözümlemesine göre incelenmiştir. Elde edilen bulgularla şikayetlerin "en fazla hangi alanlarda olduğunun belirlenmesi, kamu ve vakıf üniversitelerinin şikayetlerinin karşılaştırılması" hedeflenmiş bu doğrultuda üniversitelerin ana faaliyet alanlarına ve işleyişlerine ilişkin hizmet kalitesi bakımından şikayetlerin içeriği ile ilişkili öneriler sunulmuştur.

$\mathrm{Bu}$ çalışmaların dışında geleneksel seyahat acentelerine yönelik şikayetler üzerinden de gerçekleştirilen çalışmalar literatürde mevcuttur. Örneğin; Unur ve diğerleri (2010), çalışmalarında seyahat acentelerinin müşterilerine sundukları paket turlarla ilgili aldıkları şikayetleri hangi yollarla aldıklarını ve alınan şikayetleri nasıl çözüme kavuşturduklarını incelemiştir. Çalışma sonucuna göre seyahat acentelerinin en fazla telefon aracılığı ile şikâyet aldıkları tespit edilmiştir. Acenteler tarafından alınan şikayetlerin çözüm yönteminde ise etkileşimsel yönteme başvurulduğu belirlenmiştir.

\section{Tüketicilerin Tatminsizliklerini İletebilecekleri Bir Platform Olarak Sikayetvar.com}

Sikayetvar.com, Türkiye'de internetin henüz emekleme döneminde olduğu 2001 yılında kurulmuştur ve Türkiye'nin yurt dişına ihraç ettiği ilk iş modelidir. Kurulduğu 2001 yılından bu yana bir ürün ya da hizmetten şikâyeti olan tüketiciler ile olumsuz deneyim yaşayan müşterilerini yeniden kazanmayı amaçlayan ve potansiyel müşterilere güven aşılamayı amaçlayan markalar arasında önemli bir köprü görevi görmektedir. Sikayetvar.com, tüketicilerin markalar (işletmeler) hakkında şikâyetlerine çözüm aradığı ve diğer tüketicilerin de bu 
markalara ilişkin tüm yorumları okuduğu Türkiye'nin ilk ve en büyük e-şikâyet platformudur (www.sikayetvar.com).

Günümüzde sikayetvar.com internet sitesi, sadece müşteri şikâyetlerinin yayınlandı̆̆ 1 bir platform olarak değil, aynı zamanda siteye yöneltilen şikâyetleri ilgili firmalara ileten önemli bir mecra şeklinde de faaliyetlerini sürdürmektedir. Müşterilerin ilgili konulara yönelik şikâyetleri, bu platforma kayıtlı olan firmalar tarafından site üzerinden incelenmektedir. Platforma kayıtlı olmayan firmalara ise, telefon, faks ya da e-posta yolu ile ulaşılmaktadır (Çulha vd., 2009: 44).

$\mathrm{Bu}$ araştırmanın gerçekleştiği zaman itibari ile 1800 üzeri kurumsal üye marka olmak üzere platformda 105 binin üzerinde kayıtlı markanın yer aldığı göze çarpmaktadır. Bunlar arasında; turizm, bankacilık, otomotiv, GSM ve beyaz eşya sektörlerinde faaliyet gösteren markalar, medya, iletişim, sigortacılık ve e-ticaret sitelerinin neredeyse tümü, Türkiye ekonomisine yön veren başlıca sektörlerdeki büyük şirketlerin çoğunluğu yer almaktadır. Ayrıca 4,6 milyon bireysel üye, aylık 15 milyon ziyaretçi sayısı ve yaklaşık 80 milyon sayfa görüntüleme ile sikayetvar.com marka tercihlerini ve satın alma kararlarını etkileyen oldukça önemli ve güçlü bir mecradır. Sikayetvar.com üzerinden müşteri yorumlarını okuyanların oranı \%92 iken, şikâyet ve markaların cevaplarını okuduktan sonra satın almaktan vazgeçenlerin oranı \% 45 'tir (www.sikayetvar.com).

\section{YÖNTEM}

$\mathrm{Bu}$ bölümde araştırmanın metodolojisine yer verilmiştir. Bu kapsamda öncelikle araştırmanın amacı, devamında ise araştırmanın veri seti, verilerin toplama yöntemi ve son olarak ise araştırmada tercih edilen yöntem olan içerik analizi yöntemine ilişkin detaylar açıklanmış ve bulgulara geçilmiştir.

\section{Araştırmanın Amacı}

Dijital seyahat aracıları, turizm ve seyahat endüstrisinde geleneksel seyahat aracılarına bir alternatif olarak geliştirilen, internet teknolojilerinin tüm dünyada yaygınlaşması neticesinde tüketicilere, günün her saatinde, her yerde otel, araç kiralama ve ulaşım aracı (uçak, otobüs, tren, gemi) bileti gibi hizmetlere ilişkin rezervasyon yapabilen ve destinasyonlara yönelik bilgilendirme ve konaklama alternatifleri sunan, insanların tatil ve seyahat alışkanlıklarını kolaylaştıran, para ve zamandan tasarruf sağlayan web temelli teknolojiler kullanan aracı işletmelerdir. Bu nedenle de fiziki olarak müşterileriyle bire bir iletişime geçebilecekleri ofisleri bulunmamaktadır. Müşteriler, dijital seyahat aracıları ile ilgili şikâyetlerini yüz yüze olarak iletebilecek muhatap bulamadıklarından, memnuniyetsizliklerini ifade edecek ortam arayışındadır. Bu arayışın bir sonucu olarak ortaya çıkan sikayetvar.com üzerinde şikâyetlerini dile getirerek kurumsal olarak dijital seyahat aracılarına ulaşma imkânı bulmaktadır. Şirketlerin sikayetvar.com internet sitesi üzerinde müşterilerinin dile getirdiği şikâyetleri çözüme kavuşturmak konusunda istekli olup olmaması, şikâyetlerin e-müşteri tatminine önem verip vermediğinin de bir göstergesidir. Bu bağlamda çalışmada müşterilerin e-müşteri tatmininin bir parçası olarak, e-şikâyet konularının dijital seyahat aracıları tarafından ne şekilde işlendiğinin incelenmesi amaçlanmıştır. 


\section{Araştırmanın Veri Toplama Yöntemi}

$\mathrm{Bu}$ araştırma, nitel araştırma tekniklerinden içerik analizi yöntemi ile gerçekleştirilmiştir. Bu doğrultuda bir içerik analizi, belirli bir konudaki metin bünyesinde yer alan tüm sözlü unsurların (temalar, kavramlar, sözcükler ve deyimler gibi) ve varlıklarının seçilerek sayısal verilere dönüştürüldüğü bir araştırma tekniğidir (Seggie ve Bayyurt, 2015). Sözbilir vd., (2012)'ne göre ise bir içerik analizi belirlenen konu üzerinde gerçekleşen çalışmaların ele alınıp eğilimlerinin ve araştırma sonuçlarının tanımlayıcı bir boyutta değerlendirilmesini içeren sistematik araştırmalardır.

İçerik analizinde temel amaç, toplanan verileri açiklayabilecek kavrama ve ilişkilere ulaşabilmektir. Betimsel analizlerde özetlenip yorumlanan veriler, içerik analizinde daha derinlemesine işleme tabi tutulmaktadır. Bu sayede betimsel yaklaşım sonucunda fark edilememiş kavram ve temaların keşfedilmesi mümkün olmaktadır. İçerik analizinde temel olarak yapılan işlem, birbirine benzeyen verileri belli kavram ve temalar çerçevesinde bir araya getirip okuyucunun anlayıp algılayabileceği şekilde organize etmek ve yorumlamaktır (Selçuk vd., 2014). Çalışmada içerik analizi tekniğinin tercih edilmesinin nedeni, tüketicilerin dijital seyahat aracıları hakkındaki şikayetlerini açıkça belirttikleri bir mecranın (sikayetvar.com) olması ve bu mecraya şikayetlerinin ne hakkında olduğunu ayrıntıları ile anlatmalarıdır. Böylece tüketicilerin memnun olmadıkları konuları birinci ağızdan ayrıntılı bir şekilde öğrenmek ve bu memnuniyetsizliklerini konu başlıkları (temalar) halinde detayları ile gruplamak mümkün olmaktadır.

\section{Araştırma Verilerinin Toplanması Süreci}

Araştırmada içerik analizi yöntemi kullanılmıştır. İçerik analizinde kullanılan verilerin toplanmasında öncelikle ülkemizin en büyük ve en önemli şikâyet iletim platformlarından biri olan sikayetvar.com üzerinde haklarında şikâyet iletilen tüm dijital seyahat aracıları incelenmiştir. Bu bağlamda araştırma verilerinin toplandığı alan olarak; web sitesine kullanıcı girişi yapıldıktan sonra, "Şikayetler" sekmesi altından filtreleme yapılmış ve ardından dijital seyahat aracılarına yönelik şikayetlere ulaşılmıştır. Çalışmada veri toplama süreci boyunca, kişisel bilgilerin korunması ve ticari itibarın korunması hususuna riayet edilmiş ayrıca bilimsel araştırma ve yayın etiği prosedürüne de uyulmuştur. Bu bağlamda çalışmanın tüm süreçlerinde herhangi bir işletme ya da şahıs ile ilgili bir bilgiye yer verilmemiştir. Sikayetvar.com web sitesindeki veriler incelendiğinde, dijital seyahat aracıları ile ilgili sitenin (Sikayetvar.com) ya da dijital seyahat aracılarının kuruluşundan 28 Temmuz 2020 tarihine kadar 28 bin 94 şikayetin yayınlandığı görülmüştür. Bu şikayetlerin ise yalnızca 3781'inin çözüme kavuşturulduğu belirlenmiştir. Şikayetlerin çözüme kavuşturulma oranı \%13,45'tir. Toplamda internet sitesinde yer alan 20 farklı dijital seyahat aracısı ile ilgili şikâyetler olduğu belirlenmiş ve 20 farklı dijital seyahat aracısı hakkındaki şikayetlerin tamamı çalışmaya dâhil edilmiştir. Şikayetlerin çözüme kavuşturulma hızını da tespit edebilmek adına, araştırma sadece bir ay ile sınırlandırılmış, bu doğrultuda 28 Haziran-28 Temmuz 2020 tarih aralığındaki şikayetler incelenmiştir. Araştırma amacıyla veri toplama işlemi belirlenen tarihlerde gerçekleştirilmiştir. Veri toplama işlemi esnasında şikâyetin hangi konuda olduğu, şikâyetin kaç kez görüntülendiği, şikâyetin kaç destek aldığı (aynı şikâyeti yaşayanların sayısı), şikâyetin ne zaman yayınlandığı̆, sonuç olarak şikâyetin çözüme kavuşturulup kavuşturulmadığına yönelik bilgiler toplanmıştır. Bu işlemlerin ardından SPSS for Windows v26.0 paket programı aracılığı ile toplanan veriler analiz edilmiştir. 


\section{BULGULAR}

Araştırma kapsamında sikayetvar.com web sitesinde yer alan dijital seyahat aracılarına yönelik e-şikayetlerin yayınlanma tarihleri ile şikayetlerin çözüme kavuşturulup kavuşturulmadığına ilişkin sıklıkların dağılımları Tablo 1'de belirtilmektedir. Bu dağılımlar Şekil 1'de ise grafik olarak detaylı görülmektedir. Buna göre, 1 hafta içerisinde dijital seyahat aracılarına yönelik çözüme kavuşturulan şikayetlerin oranı \%18,44 iken, 15 gün içerisinde çözüme kavuşturulan şikâyet oranı ise yalnızca \%24,47 ile sınırlı kalmıştır. 15 gün ila 1 ay arasında çözüme kavuşturulan şikâyetlerin oranı ise \%21,78'dir. Toplamda çözüme kavuşturulan şikâyetlerin oranı incelendiğinde ise \%22,09 olduğu görülmektedir. Bu doğrultuda şikâyetlerin işletmeler tarafından çözüme kavuşturulma oranının düşük olduğu göze çarpmaktadır.

Tablo 1. Dijital Seyahat Aracıları Hakkındaki Şikâyetlerin Yayınlanma Sıklıkları ve Tarihleri

\begin{tabular}{lcccc}
\hline & & Çözüldü & Çözülmedi & Toplam \\
\hline 1-6 Gün & $\mathrm{N}$ & 71 & 314 & 385 \\
& $\%$ & 18,44 & 81,56 & 16,01 \\
7-15 Gün & $\mathrm{N}$ & 184 & 568 & 752 \\
& $\%$ & 24,47 & 75,53 & 31,28 \\
\multirow{3}{*}{ 15-30 Gün } & $\mathrm{N}$ & 276 & 991 & 1267 \\
& $\%$ & 21,78 & 78,22 & 52,70 \\
Toplam & $\mathrm{N}$ & 531 & 1873 & 2404 \\
& $\%$ & 22,09 & 77,91 & 100,00 \\
\hline
\end{tabular}

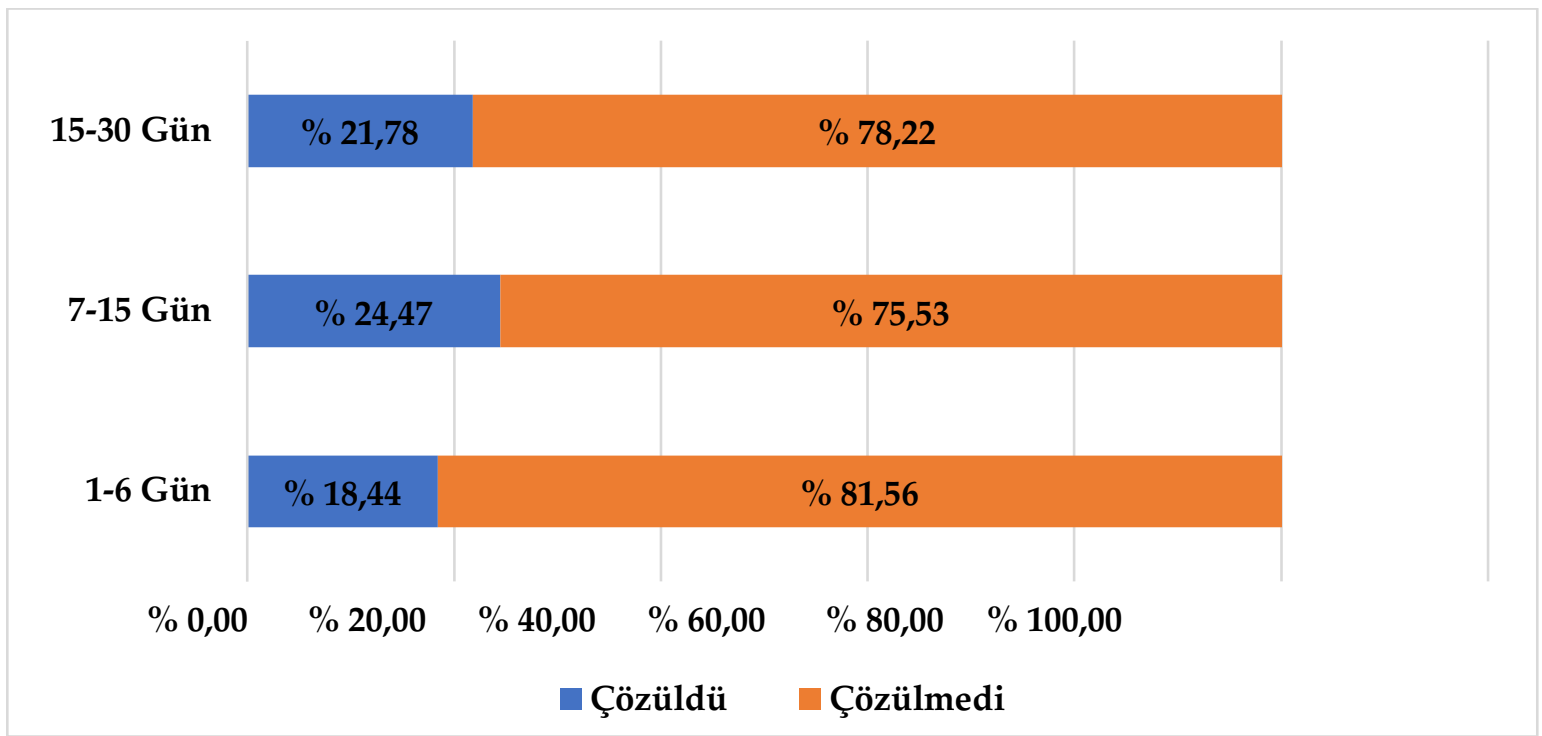

Şekil 1. Dijital Seyahat Aracıları Hakkındaki Şikâyetlerin Sonuç Grafiği

Şikâyet temalarının dağılımları ise Tablo 2' de görülmektedir. Buna göre; dijital seyahat aracıları hakkında, en fazla dile getirilen şikâyet temaları web sitesinde yer alan toplam şikayetlerin \%48,29'unu oluşturmaktadır. Bunlar; "Ücret iadesinin yapılmaması" ve "Rezervasyonun müşteri 
tarafindan iptal edilmek istenmesine kayıtsız kalinarak iptal etmemek ya da iptal etmek konusunda zorluk çıkarmaktır". Bu iki şikâyeti \%8,19 ile "Satın alım öncesindeki beklentilerin, seyahat anında / otele varınca karşılanmaması" takip etmektedir.

Araştırma kapsamında "Tur esnasında sürekli ekstralara yönlendirme" olarak belirtilen tema, tur rehberlerinin dijital seyahat aracisının internet sitesinde belirtilen destinasyon ve aktivitelerin haricinde yönlendirici bir şekilde ekstra satışlar önermesidir. Dijital seyahat aracıları hakkındaki şikâyetlerin \%6,07'si "Tur esnasında sürekli ekstralara yönlendirme" temasına ilişkin iletilen şikayetlerdir.

Araştırma kapsamında "Hatalı rezervasyon" olarak belirtilen tema, dijital seyahat aracılarından satın alınan ve müşterinin otele varmasının ardından, otelde bir rezervasyonlarının olmadığına yönelik kendilerine otel tarafından bilgilendirme yapılmasıdır. Dijital seyahat aracıları hakkındaki şikâyetlerin \% 5,20'si, "Hatalı rezervasyon" temasına ilişkin iletilen şikâyetlerdir.

Araştırma kapsamında "Tur rehberlerinin kabalığı / ilgisizliğì" olarak belirtilen tema, dijital seyahat aracısının internet sitesinde vaat edilenin aksine tur rehberlerinin tur esnasında katılımciların sorularına karşı ilgisiz davranması, soruları görmezden gelmesi ve söz ve davranışlarının kabalığıdır. Dijital seyahat aracıları hakkındaki şikâyetlerin \% 4,58'i tur rehberlerinin kabalığı ve ilgisizliğine yöneliktir.

"Zorunlu rezervasyon değişikliği" olarak belirtilen tema ise dijital seyahat aracısından satın alınan ancak oteldeki rezervasyonun dijital seyahat aracısı tarafından mücbir sebep ve gerekçe gösterilmeksizin tek taraflı ve zorunlu olarak iptal edilip, satışı yapılıp vaat edilen otel ile eşdeğer nitelikte olmayan başka bir otele rezervasyonun kaydırılmasına yönelik şikâyetlerdir. Dijital seyahat aracıları hakkındaki şikâyetlerin \% 3,66'sı bu konudan oluşmaktadır.

"Tur Koşullarında Değişiklik" olarak belirtilen tema, dijital seyahat aracısının internet sitesinde vaat edilen seyahat süresinden daha kısa bir sürenin müşteriye yaşatılması, turda öngörülen destinasyonlara gitmeme ya da var olan bir destinasyonun değiştirilerek başka bir destinasyonun tura eklenmesi / çıkarılması gibi şikâyetlerdir. Dijital seyahat aracıları hakkındaki şikâyetlerin $\% 2,83$ 'ü bu konuya ilişkindir.

"Satış sonrası ilgisizliği" olarak belirtilen tema, otelde yaşanan problemlerle ilgili olarak dijital seyahat aracısı ile iletişime geçildiğinde dijital seyahat aracısının konu ile ilgili olarak herhangi bir aksiyon almaması ya da sorunu çözüme kavuşturmak konusunda ilgisiz davranmasıdır. Dijital seyahat aracıları hakkındaki tüm şikâyetlerin \% 2,79'u bu nedenle yapılmıştır.

"Reklamların gerçeği yansıtmaması" olarak belirtilen tema, dijital seyahat aracılarının reklam epostalarında büyük puntolarla verilen promosyonların detaylı koşullarının küçük punto ile yazılıp müşteriyi yanıltması, ilgili promosyonların zorlu koşullara bağlı olmasına yöneliktir. Dijital seyahat aracıları hakkındaki tüm şikâyetlerin \% 2,04'ü bu konuya ilişkindir.

Son olarak diğer temalara kıyasla daha az sayıda şikâyet alan "Ulaşımın eski araçlarla sağlanması" olarak belirtilen tema, havaalanından otele transferi sağlayan otobüs / minibüslerin dijital seyahat aracında vaat edildiği gibi yeni ve lüks araçlarla değil, eski ve bakımsız otobüslerle sağlandığına yönelik şikâyetlerdir. Dijital seyahat aracıları hakkındaki tüm şikâyetlerin \%1,04'ü bu konuya ilişkindir.

Araştırma kapsamında bir diğer önemli bulgu ise, web sitesinde yer alan dijital seyahat aracılarının çözüme kavuşturduğu 531 şikâyetten 368'inin (\%15,31) hangi tema ile ilgili olduğu, şikâyet eden müşteri tarafından dijital seyahat aracısına teşekkür edilerek, yayından kaldırıldığı için tespit edilememiştir. 
Tablo 2. Dijital Seyahat Aracıları Hakkındaki Şikâyet Temalarının Dağılımı

\begin{tabular}{lcc}
\hline & $\mathbf{N}$ & $\mathbf{\%}$ \\
\hline Ücret iadesinin yapılmaması & 746 & 31,03 \\
Rezervasyonu iptal etmeme & 415 & 17,26 \\
Beklentilerin karşılanmaması & 197 & 8,19 \\
Tur esnasında sürekli ekstralara yönlendirme & 146 & 6,07 \\
Hatalı rezervasyon & 125 & 5,20 \\
Tur rehberlerinin kabalığı / ilgisizliği & 110 & 4,58 \\
Zorunlu rezervasyon değişikliği & 88 & 3,66 \\
Tur koşullarında değişiklik & 68 & 2,83 \\
Satış sonrası ilgisizliği & 67 & 2,79 \\
Reklamların gerçeği yansıtmaması & 49 & 2,04 \\
Ulaşımın eski araçlarla sağlanması & 25 & 1,04 \\
\hline Çözüldü / Şikâyet kaldırıldı & 368 & 15,31 \\
\hline Toplam & 2404 & 100,00 \\
\hline
\end{tabular}

\section{TARTIŞMA SONUÇ ve ÖNERILER}

Araştırma bulguları incelendiğinde dijital seyahat aracılarına yönelik, yaklaşık olarak her beş şikâyetten birinin bir hafta içerisinde, yine yaklaşık olarak her dört şikâyetten birinin ise iki hafta içerisinde çözüme kavuşturulabildiği görülmektedir. Bu doğrultuda dijital seyahat aracılarının, bildirilen bazı şikâyetlerin çözümü konusunda tam olarak yeterli desteği sağlayamadığı göze çarpmaktadır. Bu da müşterilerin dijital seyahat aracıları hakkındaki elektronik ortamdaki memnuniyetsizliğine yol açan bir unsur olarak kabul edilebilir.

Dijital seyahat aracıları hakkında şikâyet edilen temalar incelendiğinde, tüm şikâyetlerin neredeyse yarısının rezervasyonu iptal etmeme ya da iptal etme konusunda zorluk çıkarma ile iptal edilen rezervasyonun ücretinin iadesinin yapılmamasına yönelik olduğu görülmektedir. Bu bağlamda, dijital seyahat aracılarının bazı müşterilerinin maddi anlamda ciddi sorunlar yaşadığı araştırma sonucunda göze çarpmaktadır. Son dönemde her ne kadar tüm dünyayı kasıp kavuran Covid-19 pandemisi nedeni ile bu durum makul düzeyde hoş karşılanabilirse de dijital seyahat aracılarının konu üzerine daha ciddi eğilmelerinin gerekliliği açıktır. Zira bu sorunların çözümüne yönelik müşterilerin bire bir olarak fiziksel muhatap olacakları gerçek kişi bulunmadığından, ücretini ödeyip faydalanamadıkları bir hizmet nedeni ile ödedikleri ücreti geri alamamaları, tercih edilen dijital seyahat aracısı işletmeye olan müşteri güvenini sarsıcı bir durumdur. $\mathrm{Bu}$ bağlamda dijital seyahat aracılarının, mevcut müşterilerini ve gelecekte kazanacağı potansiyel müşterilerini kaybetmesi olasıdır.

Öte yandan araştırmada incelenen tüm şikâyetler arasında her altı şikâyetten birinin tur rehberleri ile ilgili olduğu görülmüştür. Dolayısıyla dijital seyahat aracılarının çalıştıkları tur rehberlerini gözden geçirmeleri gerekli görülmektedir. Tur rehberlerinin katılımcıları ekstralara yönlendirmesi, tur rehberlerinin kaba ve ilgisiz davranışları ile önceden belirlenen tur koşullarında değişiklik yapmak istemeleri konuları, müşterilerin şikâyetlerinin artmasına yol açmaktadır. Bu da dijital seyahat aracılarının müşterilerinin e-tatmini üzerinde olumsuz etkilere neden olmaktadır. 
Araştırmada, özellikle ücret iadesinin yapılmaması ve rezervasyonu iptal etmeme gibi şikayetlerin, pandemi dönemine özgü şikayetler olduğu değerlendirilmiştir. Ancak beklentilerin karşılanmaması, tur esnasında sürekli ekstralara yönlendirme, hatalı rezervasyon, tur rehberinin kabalığı/ilgisizliği, zorunlu rezervasyon değişikliği, tur koşullarındaki değişiklikler, satış sonrası ilgisizlik, reklamların gerçeği yansıtmaması ve ulaşımın eski araçlarla sağlanmasına ilişkin şikayetler pandemi dönemi koşullarından bağımsız şikayetler olarak göze çarpmaktadır.

Covid-19 pandemisi döneminde küresel ekonomi ciddi sarsıntı geçirmiştir. Temel sektörlerden biri olan turizm de bu nedenle önemli bir yara almıştır. Bu bağlamda sektörde yer alan bazı firmaların erken rezervasyonlar aracılığı ile yaptığı ciroyu ödemelerinde kullanması, buna karşılık pandemi koşulları nedeniyle konaklama işletmelerinin alınan önlemler kapsamında geçici olarak kapatılması sonucu ödeme güçlüğü doğmuştur. Buna bir de arka arkaya gelen rezervasyon iptalleri eklenince ücret iadesi konusu müşteriler ile dijital seyahat aracıları arasında önemli bir ihtilaf konusu haline gelmiştir. Bu konuda tamamen dijital seyahat aracılarına sorumluluğu yüklemek mümkün olmadığı gibi, tamamen müşterileri haklı bulmak da mümkün değildir. Zira pandemi gibi olağanüstü koşullar ve önlemler kapsamında neredeyse ülkedeki çoğu sektörün faaliyetlerinin durdurulması durumu vardır. Ancak yine de müşterilerin ödeme yapmış olmasına rağmen hizmet alamamış oldukları unutulmamalıdır. Bu nedenle de dijital seyahat aracılarının müşteri şikayetlerini daha hızlı işleyerek ücret iadeleri konusunda fedakarlıkta bulunmaları beklenmektedir.

Öte yandan beklentilerin karşılanmaması, reklamların gerçeği yansıtmaması, müşterilerin rezervasyon değişikliğine zorlanması gibi şikayet konuları, doğrudan dijital seyahat aracılarından kaynaklanan şikayetlerdir. Müşterilerin seyahat hizmeti satın almak istediklerinde tamamen dijital seyahat aracısına güvenmek zorunda olduğu, sitede gösterilen bilgiler ve fotoğraflar doğrultusunda çıplak gözle görmedikleri odaları, kahvaltı ve yemek servisini, animasyonları, otelin fiziksel imkanlarını satın aldıkları düşünüldügünde, dijital seyahat aracılarından internet sitelerinde yer alan bilgileri en doğru şekilde sunulması beklenmektedir. Çünkü potansiyel müşteriler ne zaman çekildiği belli olmayan profesyonel fotoğraflarda mükemmel gözüken koşullara göre beklenti oluşturmakta, bu koşulları talep edip hizmeti satın alabilmektedir. Ancak sitede sunulan ile gerçekte karşılaşılan durum arasında fark olması, doğal olarak şikayet konusu olmaktadır. Bu bağlamda dijital seyahat aracılarının internet sitesinde sundukları bilgileri mümkün olan en güncel şekilde ve dürüstlük ilkesine bağlı olarak sunulması gereklidir.

Çalışmada sonuç olarak dijital seyahat aracılarının şikâyetleri çözüme kavuşturmak konusunda; mevcut konulardaki eksikleri gidererek, gerekirse bu alanda daha fazla nitelikli personel istihdam ederek e-müşteri tatmini ve müssteri sadakati sağlama yoluna gitmesinin gerekliliği gelecek adına kaçınılmazdır. Unutulmamalıdır ki, herhangi bir konuya ilişkin bir şikâyet söz konusu olduğunda çoğunlukla, sadece şikâyeti ileten müşteriler değil, dijital seyahat aracısı işletmelerden hizmet satın alan tüm müşteriler rahatsız olmaktadır. Bu doğrultuda bir şikâyete konu olan sorunun ilgiyle çözülmesi, sadece o şikâyeti siteye (www.sikayetvar.com) yönelten müşterinin değil, tüm müşterilerin memnuniyetini etkilemektedir.

Bu bağlamda sorunların çözümü adına sektörde aşağıdaki adımların atılması önerilebilir;

- Şikayetleri çözüme kavuşturmak için daima müşteri memnuniyeti odaklı, proaktif yaklaşımlar sergilenmesi,

- Şikayetleri çözüme kavuşturmak için müşteri hizmetleri personeline eğitim verilmesi ve problemlerin çözümü için yetkilerin artırılması,

- Dijital seyahat aracıları personelinin bilgi, beceri ve davranışlarının olumlu yönde değişimini sağlayan eğitimlerin kalitesinin arttırılması, 
- Ücret iadelerinin yapılabilmesi için şirketin maddi olanaklarını artıracak girişimlerde bulunması, gerekirse bankalar aracılığı ile sorunların çözülmesi,

- Tur rehberleri ile ilgili yoğun şikayetler nedeniyle daha fazla kalifiye tur rehberlerinin istihdam edilmesi, tur rehberlerinin, turlarda sürekli ücretli ekstralara yönlendirmesinin önüne geçilebilmesi adına gerekirse yaptırımların uygulanması,

- İşletmeler tarafından özellikle turlardaki rehberlik hizmetlerinin denetiminin daha sağlıklı bir şekilde yapılması ve standardizasyonun sağlanması.

Görüldüğü üzere bu çalışma, literatürde yer alan, e-şikayet temalarının incelendiği ve eşikayetlerin nasıl ele alındığının araştıııldığı öncül çalışmalara (Çulha vd., 2009, Unur vd., 2010) ek olarak, şikayetlerin çözüme kavuşturulup kavuşturulmadığını ortaya koymaktadır. Geçmiş çalışmalardan farklı olarak ise iletilen e-şikayetlerin çözüme kavuşturulma hızının belirlemesi açısından ilgili literatüre katkı sağlamayı hedeflemektedir. Bu doğrultuda gelecek çalışmalar için de yararlanılacak bir çalışma niteliğinde olacağı öngörülmektedir.

\section{KAYNAKÇA}

Anderson, R.E. and Srinivasan, S.S. (2003). E-Satisfaction And E-Loyalty: A Contingency Framework. Psychology and Marketing, 20(2): 123-138.

Arıca, R. ve Kozak, R. (2018). Seyahat Acentalarında Müşterilerin Üretime Katılım Davranışının Algılanan Hizmet Çıktılarına Etkisi. Seyahat ve Otel Işsletmeciliği Dergisi, 15 (3): 684-702.

Lütfi, A. Y. (2009). Bilgi Teknolojisindeki Gelişmelerin Seyahat Acentalarına Yansımaları; Online Seyahat Acentacılığı. Sosyal Ekonomik Araştırmalar Dergisi, 9(17), 117-136.

Yazıcı Ayyıldız, A. ve Baykal, M. (2020). Otel İşletmelerine Yönelik E-Şikâyetlerin İçerik Analizi ile İncelenmesi: Kuşadası 5 Yıldızlı Otel İşletmeleri Örneği. OPUS Uluslararası Toplum Araştırmaları Dergisi, 16 (30), 2659-2683.

Buluk, B. ve Boz, M. (2016). Online Seyahat Acenteleri Aracılığıyla Seyahat Satın Almada Turist Memnuniyeti: İstanbul Örneği. Karabük Üniversitesi Sosyal Bilimler Enstitüsü Dergisi, 6(2): 504-529.

Cevher, E. (2016). Hizmet Kalitesi Açısından Üniversitelere Yönelik Şikayetlerin İncelenmesi. Journal of Yasar University, 11(43), 163-171.

Christodoulides, G. and Michaelidou, N. (2010). Shopping Motives as Antecedents of ESatisfaction and E-Loyalty. Journal of Marketing Management, 27(1-2): 181- 197.

Çetinsöz, B. C. (2016) The Impact of E-Satisfaction and Confidence Aspects on Web Site Loyalty in Terms of Online Shopping in Tourism: A Study on Domestic Tourists in Turkey. European Journal of Business and Management, 8(17): 36-48.

Çulha, O., Hacıoğlu, G., ve Kurt, G. (2009). Otel Müşterilerinin E-Şikayetlerine Yönelik Bir İçerik Çözümlemesi. Seyahat ve Otel İşletmeciliği Dergisi, 6(4), 42-49.

Dinçer, M. Z. and Alrawadieh, Z. (2017). Negative Word of Mouse in the Hotel Industry: A Content Analysis of Online Reviews on Luxury Hotels in Jordan. Journal of Hospitality Marketing and Management, 26 (8), 785-804.

Gharibi, N., Rudsari, S.M. and Nasouti, M. (2020). Tourists' E-Loyalty to a Destination Website: A Case of an Iranian Tourism Website. International Journal of Tourism Policy, 10(1).

Husain, A., Varshney, T., Bhatnagar, S. and Satsangi, A. K. (2019). E-Satisfaction Towards Cashless Transactions: Re-Tests Model for E-Tourism. International Journal of Advance and Innovative Research, 6(2), 65-73. 
İçöz, O. (2003). Seyahat Acentaları ve Tur Operatörlüğ̈̈ Yönetimi, Ankara: Turhan Kitabevi.

Kozak, N. (2004). Turizmde Aracı Kurumların Geleceğe Yönelik Beklentileri Türkiye'de Faaliyet Göstermekte Olan Seyahat Acenteleri Üzerine Bir Araştırma. Ankara: Detay Yayıncllık.

Kozak, R. ve Cingi, C.C. (2019). Çevrimiçi Platformların Konaklama Sektörüne Etkileri. Türk Turizm Araştırmaları Dergisi. 3(3): 174-187.

Kutlu, D., Ayyıldız, H. ve Koç, N. K. (2019). A Grubu Seyahat Acentalarında Bilgi Teknolojilerinin Kullanımına Yönelik Bir Araştırma: Antalya Örneği. Global Journal of Economics and Business Studies, 8(15), 40-51.

Long, Y. and Shi, P. (2017). Pricing Strategies of Tour Operator and Online Travel Agency Based on Cooperation to Achieve O2O Model. Tourism Management, 62, 302-311.

Luo, S.F. and Lee, T.Z. (2011). The Influence of Trust and Usefulness on Customer Perceptions of E-Service Quality. Social Behavior and Personality, 39(6): 825-838.

Mahadin, B., Akroush, M.N. and Bata, H. (2020). The Effects of Tourism Websites' Attributes on E-Satisfaction And E-Loyalty: A Case of American Travelers' to Jordan. International Journal of Web Based Communities, 16(1), 4-33.

Mohammed, M.E., Wafik, G. M., Jalil, S.G. and Hassan, Y.A. (2016). The Effects Of E-Service Quality Dimensions on Tourist's E-Satisfaction. International Journal of Hospitality and Tourism Systems, 9(1),12-20.

Pereira, H. G., Salgueiro, M.F. and Rita, P. (2017). Online Determinants of E-Customer Satisfaction: Application to Website Purchases İn Tourism. Service Business, 11(2), 375-403.

Ronsana, G.G., Shibab, M.R., Syahbuddin, B.H. and Fitriani, W.R. (2018). Factors Influencing Customer's E-Loyalty in Tourism E-Marketplace. 2018 International Conference on Information Technology Systems and Innovation (ICITSI).

Şahin, S. (2018). Konaklama İşletmelerinde İlişkisel Pazarlama Uygulamalar ile Müşteri Şikâyet Davranışı ve Tekrar Satın Alma Niyeti Arasındaki İlişkinin Belirlenmesi: Turizm Akademisyenleri Tarafindan Bir Değerlendirme, Doktora Tezi. Atatürk Üniversitesi, Erzurum.

Şahin, S., Girgin, G. K. ve Kazaoğlu, İ. H. (2018). Gastronomi Turistlerinin E-Şikâyet Davranışları Üzerine Bir Araştırma: Alaçatı, Journal of Tourism And Gastronomy Studies, 6(1), 68-82.

Saçlı, Ç. ve Yurtlu, M. (2020). Otellerin Çevrimiçi Rezervasyon Motoru Kullanımı Ve Yorum Siteleri Entegrasyonu Üzerine Nitel Bir Araştırma: Hatay Otelleri Örneği. Turizm Akademik Dergisi, 7(2), 37-59.

Seggie, F.N. ve Bayyurt, Y. (2015). Nitel Araştırma. Yöntem, Teknik, Analiz ve Yaklaşımları. Ankara: Anı Yayıncilık.

Selçuk, Z., Palancl, M., Kandemir, M. ve Dündar, H. (2014). Eğitim ve Bilim Dergisinde Yayınlanan Araştırmanların Eğilimleri: İçerik Analizi. Eğitim ve Bilim, 39(173), 430-453.

Sikayetvar.com. (2020). Hakkımızda. https://www.sikayetvar.com/hakkimizda (Erişim Tarihi: 29.07.2020).

Sözbilir, M., Kutu, H. and Yaşar, M. D. (2012). Science education research in Turkey: A content analysis of selected features of papers published. In J. Dillon and D. Jorde (Eds). The World of Science Education: Handbook of Research in Europe (pp.341-374). Rotterdam: Sense Publishers.

Tang, L. and Jang, S.S. (2008). Tourism Information Trust as a Bridge Between Information Value and Satisfaction: An Exploratory Study. Tourism Analysis, 13(5-6): 565-578. 
Unur, K., Çakıcı, C. ve Taştan, H. (2010). Paket Turlardaki Müşteri Şikâyetleri ve Seyahat Acentalarının Bu Şikâyetlerle Karşılaşma Sıklıkları Üzerine Bir Araştırma. Ç.Ü. Sosyal Bilimler Enstitüsü Dergisi, 19(3), 391-408.

Yapraklı Ş. ve Yılmaz, M.K. (2008). İnternet Bankacıllğı Hizmeti Kullanıcılarının Hizmet Kalitesi Algılarının Tatmin ve Bağlllık Düzeyleri Üzerindeki Etkisi; Akademik Personel Üzerinde Bir Uygulama. Marmara Üniversitesi İktisadi ve İdari Bilimler Dergisi, 24(1): 137-161. 